\title{
Antioxidants in Cancer Therapy: Recent Trends in Application of Nanotechnology for Enhanced Delivery
}

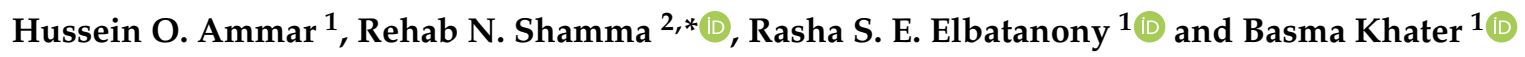 \\ 1 Department of Pharmaceutics and Pharmaceutical Technology, Faculty of Pharmaceutical Sciences and \\ Pharmaceutical Industries, Future University in Egypt, Cairo 11835, Egypt; \\ drhusseinammar@hotmail.com (H.O.A.); rashaelbatanony@hotmail.com (R.S.E.E.); \\ basma-khater@outlook.com (B.K.) \\ 2 Department of Pharmaceutics and Industrial Pharmacy, Faculty of Pharmacy, Cairo University, Kasr El-Aini \\ Street, Cairo 12613, Egypt \\ * Correspondence: rehab.shamma@pharma.cu.edu.eg
}

Received: 5 November 2019; Accepted: 31 December 2019; Published: 21 January 2020

\begin{abstract}
Recently, the occurrence of cancer has significantly increased; it represents the second-most frequent cause of death after cardiovascular diseases. Many dietary antioxidants have shown large impact as effective agents for cancer prevention by reducing oxidative stress, which has been a part in the development of many diseases, including cancer. One of the obstacles in the delivery of antioxidant therapies into the required domain lies in the inadequate delivery of these agents to their intended site of action. Using nanotechnology in delivery of antioxidants leads to increased therapeutic index and higher drug concentration in tumor tissues, thus enhancing anticancer treatment. In this review, we discuss the role of different antioxidants in cancer therapy and their improved therapeutic effect through their formulation using nanotechnology.
\end{abstract}

Keywords: nanotechnology; antioxidants; cancer therapy

\section{Introduction}

Cancer is considered the second most frequent cause of death worldwide after cardiovascular disease. Although great improvements have been made in cancer therapy, it is still a major health concern and, therefore, various investigations have been done to develop new therapeutic approaches [1].

Cancer involves uncontrolled growth of cells and it can develop in any tissue. The basic process of different types of cancer is similar; it begins when a cell has a faster rate of cell division than normal cells. The initiation of cancer is highly linked to oxidative stress that results in DNA damage, instability of genome and cell proliferation [2]. Various researchers have reported the mechanism by which oxidative stress can lead to chronic inflammation, which leads to many diseases including cancer [3].

Compared to normal cells, cancer cells have a concentration of endogenous reactive oxidative stress (ROS) [4,5]. Low concentrations of ROS compounds are required for signal transduction, but a cancer cell has an accelerated metabolism, thus they need high ROS concentrations to maintain their high proliferation rate. They cause damage in mitochondrial DNA, which leads to mutation in the oxidative phosphorylation resulting in increase in production of ROS. It aids in the proliferation of cancer cells, which leads to an increase in tumor growth [6]. That is why cancer cells require high ROS concentrations to maintain their high proliferation rate.

ROS damage in cells depends on their intracellular concentration and on the equilibrium between the ROS and the endogenous antioxidant species. Oxidative stress is generated as a result of the loss of 
the pro-oxidant/anti-oxidant equilibrium. This oxidative stress alters and damages many intracellular molecules such as proteins, lipids, DNA and RNA [7].

The generation of oxidative stress is caused by the imbalance between reactive oxidative stress production and the deficiency of the cell antioxidant defense system [8]. This imbalance leads to damage of important cells as it affects the whole organism. Many forms of chemotherapy and radiation therapy act through oxidative stress pathways [9-11]. Various researchers have reported the mechanism by which oxidative stress can lead to chronic inflammation, which leads to many diseases including cancer [3].

Reactive oxygen species (ROS) are products of metabolic reactions in the mitochondria of eukaryotic cells. Low concentrations of ROS compounds are required for signal transduction, but cancer cell has an accelerated metabolism, thus they need high ROS concentrations to maintain their high proliferation rate.

The generation of oxidative stress is caused by the imbalance between reactive oxidative stress production and the deficiency of the cell antioxidant defense system [8]. This imbalance leads to damage of important cells as it affects the whole organism. Many forms of chemotherapy and radiation therapy act through oxidative stress pathways [9-11].

Various studies reported that cancer patients showed low antioxidant level and increased oxidative stress, even before start of the treatment. Sharma et al. [12] has evaluated patients with tongue carcinoma, results showed that pretreatment levels of plasma lipid peroxide and conjugated dines were significantly elevated in patients with carcinoma, as compared with controls.

Antioxidants are effective in scavenging free radicals [13,14]. The first definition of antioxidant was proposed by Halliwell et al. [15] as "any substance that, present in low concentrations compared to oxidizable substrates (carbohydrates, lipids, proteins or nucleic acids), significantly delays or inhibits the oxidation of the mentioned substrates". Antioxidants attract a huge interest in cancer therapy, where they eliminate oxidizing free radicals, thus prevent cellular damage, which is helpful in chemotherapy [16]. Different articles have investigated antioxidant supplements during chemotherapy in order to protect normal tissues without adversely influencing tumor therapy.

There are two kinds of antioxidants doses used in cancer therapy: a preventive low dose, which provides protection of normal cells and tumor cells and a therapeutic high dose, which inhibits the growth of cancer cells without affecting normal cells. Recent reviews proved that administration of antioxidants with chemotherapy has the following advantages: (a) they do not interfere with chemotherapy and (b) they improve the cytotoxic effect of chemotherapy while protecting the normal tissue thus increase the patient survival and therapeutic response $[17,18]$.

\section{Nanotechnology for Antioxidants Delivery}

Application of nanotechnology for delivery of antioxidants has been reported to enhance their therapeutic benefits in cancer therapy. Nanoparticles (NPs) have size between 1 and $100 \mathrm{~nm}$. Nanoparticles for drug delivery may have different composition, size and shape. They also may differ in drug loading capacity, particle and drug stability, drug release rates, and targeted delivery ability.

Different examples of nano-systems have been reported in the literature including:

\subsection{Dendrimers}

Dendrimers are homogenous, symmetric around the core and consist of two shells (inner shell and an outer shell). There are different types of dendrimers with different properties including polyvalency, self-assembling, electrostatic interactions, chemical stability, low cytotoxicity and solubility. These varieties are one of the reasons to use dendrimers in the medical application [19].

Dendrimers may carry the drug by attachment of drug molecule to the functional groups on their surface or incorporation in the interior environment of the sphere $[20,21]$. Dendrimers are helpful in carrying both hydrophobic and hydrophilic molecules for delivery of genes, drugs and anticancer agents. Zhang et al. developed multifunctional doxorubicin conjugated poly (amidoamine) dendrimers 
for $\mathrm{pH}$-responsive drug release and targeted cancer therapy [22]. Another study by Liu et al. confirmed the efficacy of antioxidant response via delivery of curcumin using dendrimers as a carrier system in cancer therapy [23].

\subsection{Micelles}

Micelles are self assembled nanosized colloidal dispersions [24,25]. Their surfactant molecules can be aggregated either by cationic, anionic, zwitterionic or non-ionic groups [26] depending on the type of head groups and length of the alkyl chains [27,28]. They consist of both hydrophobic and hydrophilic shells, thus they are used for carrying both hydrophilic and lipophilic molecules [21].

Micelles have attracted attention for their potential use in cancer diagnosis and therapy. A study was done by Masaki et al. showed that antioxidant micelles containing catechol moieties can be used in anti-angiogenic therapy to treat various diseases including cancer [29].

Another study by Esmaili et al. reported that curcumin-loaded micelles showed an increase in curcumin solubility and bioavailability in treatment of cancer [30].

\subsection{Polymeric Nanoparticles}

Polymeric nanoparticles are solid colloidal systems that can carry drugs in different ways, either by dissolving, entrapping, encapsulating or adsorbing the drug onto their matrix. Depending on the formulation method, the obtained polymeric particle may be nanospheres, which are matrix systems in which the drug is dispersed throughout the particles, or nanocapsules, which are vesicular reservoir systems in which the drug is confined to an aqueous or oily cavity surrounded by a single polymeric membrane [31].

In a study by Mady and Shaker on the preparation of ellagic acid-polymeric nanoparticles using the emulsion-diffusion-evaporation method, the results showed that they were able to sustain the diffusion release of ellagic acid and enhance its cytotoxicity (6.9-fold) against the colon adenocarcinoma, thus improved ellagic acid bioavailability and its anticancer efficacy [32]. Rocha et al. also proved the efficacy of using polymeric nanoparticles in delivery of catechin for prostate cancer treatment [33].

\subsection{Liposomes}

Liposomes are spherical vesicles consisting of two layers of lipids with an internal aqueous cavity. They are composed of phospholipids or synthetic amphiphiles incorporated with sterols, such as cholesterol to influence membrane permeability.

Liposomal encapsulation has been reported to alter the biodistribution of compounds, such as doxorubicin [34,35] and vincristine [36] to limit systemic drug-induced toxicities. A study by Koudelka et al. was done to formulate vitamin E liposomes for treatment of cancer, where liposomes could reduce immunotoxicity, thus it was helpful for the combined chemo-and immuno-therapy [37].

Muthu et al. incorporated vitamin $\mathrm{E}$ in liposomal formulation for the delivery of vitamin $\mathrm{E}$ to target brain cancer cells. Their results showed that liposomes had a great efficacy in targeting cancer cells as a multifunctional carrier [38].

\subsection{Solid Lipid Nanoparticles}

Solid lipid nanoparticles (SLNs) are lipid-based nanocarriers, which are solid in the body temperature and stabilized by emulsifiers [8]. SLNs can protect the incorporated drug from the surrounding harsh environmental situations. Their biodegradability and biocompatibility also make them suitable to be used as a drug carrier systems [39]. They can overcome some of the obstacles of other nano-systems, where their large scale production is lower in cost, and have fewer storage and drug leakage problems in comparison to liposomes [8,40,41].

Various reviews have described the different types of SLNs, characterization methods, preparation techniques, structural properties, factors that may affect their formation and storage stability, drug loading and drug release principles $[8,42,43]$. 


\section{Methods of Preparation of SLNs}

Several methods have been adapted for the preparation of SLNs, including:

\subsection{High Pressure Homogenization Technique}

This technique includes two strategies, hot homogenization and cold homogenization.

Hot homogenization is carried out at temperatures above the melting point of the lipid, while in the cold homogenization process, solubilization of the drug in the lipid is first done, followed by rapid cooling [44]. The cold homogenization can overcome the obstacles of hot pressure homogenization such as degradation [44]. Müller et al. suggested using cold homogenization technique, which is performed at room temperature to increase aqueous solubility of the drug $[45,46]$.

\subsection{Microemulsion Technique}

The concept of microemulsion technique was introduced in the early 1940s by Hoar and Schulman [47]. Microemulsions are thermodynamically stable systems composed of a hydrophilic, a hydrophobic and an amphiphilic component, with the globules are in the nano-size range [48].

\subsection{Solvent Emulsification Evaporation Technique}

In this technique, a water immiscible organic phase containing the lipophilic material (lipid) and the lipophilic drug is emulsified by homogenization in an aqueous phase followed by evaporation of the organic solvent by mechanical stirring at room temperature, resulting in the formation of lipid precipitates as SLNs $[49,50]$.

\subsection{Solvent Emulsification Diffusion Technique}

This technique depends on dissolving the lipid and the drug in a partially water miscible organic solvent (e.g., benzyl alcohol, butyl lactate, ethyl acetate, isopropyl acetate and methyl acetate), then the organic solvent is emulsified using an emulsifying agent dissolved in an aqueous phase under agitation. Once emulsion is formed, SLNs are obtained by evaporation of the solvent under low pressure [51].

\subsection{Ultrasonication Technique}

In this technique, the drug is added to the dissolved lipid, then the aqueous phase added to the dissolved lipid phase and emulsified by sonication at high speed stirring. Ultrasonication technique was initially used for the production of solid lipid nanodispersion [52]. However, one of the drawbacks of this method is the physical instability of the prepared SLNs [53].

\subsection{Melting Dispersion Technique (Hot Melt Encapsulation Method)}

In this technique, the molten solid lipid containing the drug is emulsified into the heated aqueous phase. Following this, the system is allowed to cool down to room temperature resulting in the formation of SLNs. This method is better than the ultrasonication method, but less than the solvent emulsification evaporation method in terms of reproducibility $[54,55]$.

\subsection{Double Emulsion Technique}

Production of SLNs by double emulsion technique involves the dissolution of the drug (mainly hydrophilic drug) in an aqueous solvent (inner aqueous phase) followed by dispersion in lipid containing emulsifier/stabilizer, known as oil phase, to produce primary emulsion (w/o). Following this, a double emulsion $(\mathrm{w} / \mathrm{o} / \mathrm{w})$ is formed through the introduction of an aqueous solution containing the hydrophilic emulsifier under stirring and finally isolated by filtration $[56,57]$. Double emulsion technique is suitable for the preparation of protein and peptide-loaded lipid nanoparticles, as it does not involve a heating process. Moreover, the surface of the nanoparticles can be modified to sterically 
stabilize them through the incorporation of a lipid-PEG derivative, resulting in improved resistance in the gastrointestinal fluids [58].

\subsection{Solvent Injection Technique}

In this technique, the lipid and drug are first dissolved in a water miscible solvent, and then the mixture is injected in an aqueous phase through an injection needle. The resulting dispersion is filtered to obtain the prepared SLNs [53]. Solvent injection technique has several advantages such as the ability of using pharmacologically acceptable organic solvent, easy to handle and fast production process.

Other methods used for preparation of nanoparticles (Table 1).

\subsubsection{Desolvation Technique}

This technology is applicable for a wide range of polymers by changing the charge and $\mathrm{pH}$ by addition of a desolvating agent like ethanol or concentrated organic salt solution [59].

\subsubsection{Dialysis Technique}

Dialysis technique is a simple and effective technique for preparation of polymeric nanoparticles with narrow distribution. Briefly, drug and polymers are placed inside a dialysis tube/membrane after dissolving with water miscible organic solvents with appropriate molecular weight cut off. The organic phase diffuses out through the dialysis tube/membrane into the aqueous phase which decrease the interfacial tension between them [60].

\subsubsection{Nanoprecipitation Technique}

Nanoprecipitation technique was first introduced by fessi for preparation of polymeric nanoparticles, where formation of particles is based on the precipitation and subsequent solidification of the polymers due to the interfacial deposition of polymer after displacement of semi polar solvents miscible with water, from a lipophilic solution [61].

\subsubsection{Solvent Evaporation Technique}

Solvent evaporation technique is commonly used for preparation of polymeric nanoparticles. Briefly, the polymer is dissolved in an organic solvent into which the drug is dissolved/dispersed [62].

\section{Examples on Utilizing Nanotechnology in the Delivery of Antioxidants for Cancer Therapy}

The therapeutic benefits of applying nanosystems fabrication techniques in delivering various antioxidants have been listed in Table 2.

\subsection{Vitamin $E$}

Vitamin E is a lipophilic component in the cell antioxidant defense system and can be obtained from the diet, its important role in the body is related to its antioxidant activity [63]. It has been shown to enhance the cytotoxic effect of anticancer drugs, including 5-fluorouracil [64], vincristine [65] and doxorubicin $[66,67]$. Studies on animals have shown that parenteral administration of vitamin $\mathrm{E}$ resulted in enhancing the anticancer effect of 5-FU [68] and cisplatin [69]. Feng et al. have developed systems of nanoparticles of biodegradable polymers for oral administration of anticancer drugs, with the incorporation of vitamin E using modified solvent extraction/evaporation [70].

\subsection{Coenzyme Q10 (Ubiquinone)}

Co-enzyme Q10 (Co-Q10) is a lipophilic antioxidant that has the ability to prevent lipid peroxidative damage of mitochondrial membranes. A study done by Hurley et al. showed that parenteral administration of Co-Q10 was able to prevent acute doxorubicin-induced cardiotoxicity in animals [71]. In a study done by Nehilla et al. Co-Q10-loaded surfactant-free biodegradable poly (lactic-coglycolic 
acid) (PLGA) nanoparticles were prepared using nanoprecipitation method, which resulted in sustained drug delivery due to the extended C-oQ10 release [72].

\subsection{Vitamin C}

Vitamin $C$ is a versatile hydrophilic antioxidant that can protect against lipid peroxidation by scavenging ROS in the aqueous phase before initiation of lipid peroxidation. Pohl and Reidy have proven that oral administration of vitamin $C$ to human volunteers lead to protection against chemotherapy induced mutagenesis [73]. Supplementation with vitamin $C$ has significantly reduced the chromosomal damage, indicating that vitamin $C$ could reduce the chemotherapy-induced carcinogenesis. In their study, Duarah et al. [74] studied the loading of Vitamin C into ethyl cellulose nanoparticles by the solvent evaporation method for effective delivery to the skin layers.

\section{4. $\beta$-Carotene}

$\beta$-carotene is a lipophilic antioxidant produced by microorganisms and plants. In a study done by Teicher et al. $\beta$-carotene was found to improve the cytotoxicity effect of melphalan on human carcinoma cells [75] and of cisplatin and dacarbazine on melanoma cells [76]. Another study by Seang Chu et al. reported that $\beta$-carotene nanodispersions prepared by emulsification-evaporation method could increase the gastrointestinal absorption of lipophilic drugs [77].

\subsection{Resveratrol}

Resveratrol is a natural polyphenol and phytoalexin, it has numerous therapeutic effects including anticancer, antioxidant and anti-inflammatory effects. However, its poor pharmacokinetic properties, low aqueous solubility, low photostability and extensive first pass metabolism, resulted in its poor bioavailability. In their study, Kampa et al. reported that resveratrol could effectively inhibit the growth of prostate cancer cells [78]. Manna et al. have shown that resveratrol is capable of inhibiting reactive oxidative stress and lipid peroxidation induced by tumor necrosis factor in wide variety of cells [79]. Several studies reported the nanoencapsulation of resveratrol in order to enhance its anti-tumor activity. In their study, Thipe et al. [80] reported the preparation of resveratrol-conjugated gold nanoparticles: in order to increase the anti-tumor efficacy against breast, pancreatic and prostate cancers. Another study by Penalva et al. [81] reported the enhanced oral bioavailability of resveratrol through its encapsulation of casein nanoparticles.

\subsection{Curcumin}

Curcumin is extracted from curcuma rhizomes, through crystallization by extraction with solvent and extract purification. Since inflammation is highly linked to tumor promotion, curcumin is considered as a chemopreventive agent due to its anti-inflammatory and antioxidant effects on carcinogenesis [82]. Although it is a great bioactive agent and natural antioxidant but it has some disadvantages such as water insolubility and low bioavailability [83]. To overcome this problem, curcumin nanoparticles were formulated [84]. Das, Kasoju developed curcumin-loaded tripolymeric composite nanoparticles using ionotropic pre-gelation followed by polycationic cross-linking for the delivery to cancer cells. Results showed that these composite nanoparticles could successfully deliver curcumin into cancer cells [85].

\subsection{Catechin}

Catechin is a herbal flavonoid with great antioxidant activities [86]. However, only few clinical studies are carried out on humans, owing to its very low bioavailability due to rapid elimination from liver by biliary excretion, when administered in vivo [87]. In a study done by Kaur et al. results showed that treatment of mammary adenocarcinoma mice with catechin from green or black tea resulted in an increase in the survival time and decreased the tumor load [88]. Hu, Pan et al. have developed 
chitosan-tripolyphosphate nanoparticles using cross linking technique as carriers for delivering tea catechins successfully in a controlled manner [89].

\subsection{Rutin}

Rutin (RT) is a natural flavonoid widely distributed in medicinal herbs, food and other products, and possess powerful antioxidant, anti-inflammatory and anticancer properties. Owing to its immense antioxidant potential, it has been reported to exhibit therapeutic potential in diverse variety of cancers including hepatic cancer. Despite its diverse therapeutic merits, RT shows poor aqueous solubility, which results in low oral bioavailability, which further limits its therapeutic potential in cancer therapy. A study which was done to investigate the chemoprotective effects of RT, reported that this antioxidant induced favorable changes in the antioxidant defense system in cancer therapy [90]. In a study by Zhang et al. [91], the antioxidant activity of rutin was improved via incorporation into zein-sodium caseinate nanoparticles.

\subsection{Baicalin}

Baicalin (BA) is a flavonoid extracted from Scutellaria baicalensis Georgi. It has numerous biological activities including anti-inflammatory, antibacterial, antioxidant and anticancer effects $[92,93]$. Increasing evidence suggests that BA has strong capacity to inhibit tumor growth in various cancers [94,95]. A study by Chen et al. reported that BA effectively inhibited viability of ovarian cancer cells [96]. In addition, BA could retard cancer progression by inhibiting invasion and metastasis of cancer cells [97].

Studies reported that concomitant administration of BA and vitamin C could suppress lung carcinoma and lung metastasis [98,99], and suppress tumor growth in hepatic cancer [100]. Zhao et al. have developed BA loaded cationic solid lipid nanoparticles prepared by emulsion evaporation-solidification at low temperature method for brain targeting as a carrier for drugs through blood brain barrier [23].

\section{Conclusions}

Various studies have proved that using antioxidants during cancer therapy is a promising trend to improve response to chemotherapy, avoid/reduce side effects associated with chemotherapy and maintain the cellular integrity, thus maintain the homeostasis of the host immune system. In this review, several antioxidants with different therapeutic benefits in cancer therapy have been discussed. Moreover, several studies focusing on the application of nanotechnology in delivery of these antioxidants have been shown and proven promising results in enhancing their therapeutic benefits in cancer therapy. Therefore, further preclinical and clinical studies are needed to establish the clinical implications of antioxidants doses and timings.

Table 1. Advantages and disadvantages of different methods of preparation of solid lipid nanoparticles (SLNs).

\begin{tabular}{lll}
\hline \multicolumn{1}{c}{ Method } & \multicolumn{1}{c}{ Advantages } & \multicolumn{1}{c}{ Disadvantages } \\
\hline & -Low impact on the environment & \\
& -Sustainable & \\
High pressure & -Saving energy, time and additional costs [101] \\
homogenization & -Hot homogenization has a problem of drug entrapment and & Low efficiency of the process [103] \\
Technique & crystallization, Cold homogenization minimizes thermal & \\
& exposure of the drug but does not avoid it completely, due to the & \\
& melting of the drug-lipid mixture in the initial step [102]. & Their formation requires large \\
& -Spontaneous formation & amounts of surfactant which are \\
Microemulsion & -Ease of manufacturing & irritating at high concentrations [105] \\
\hline
\end{tabular}


Table 1. Cont.

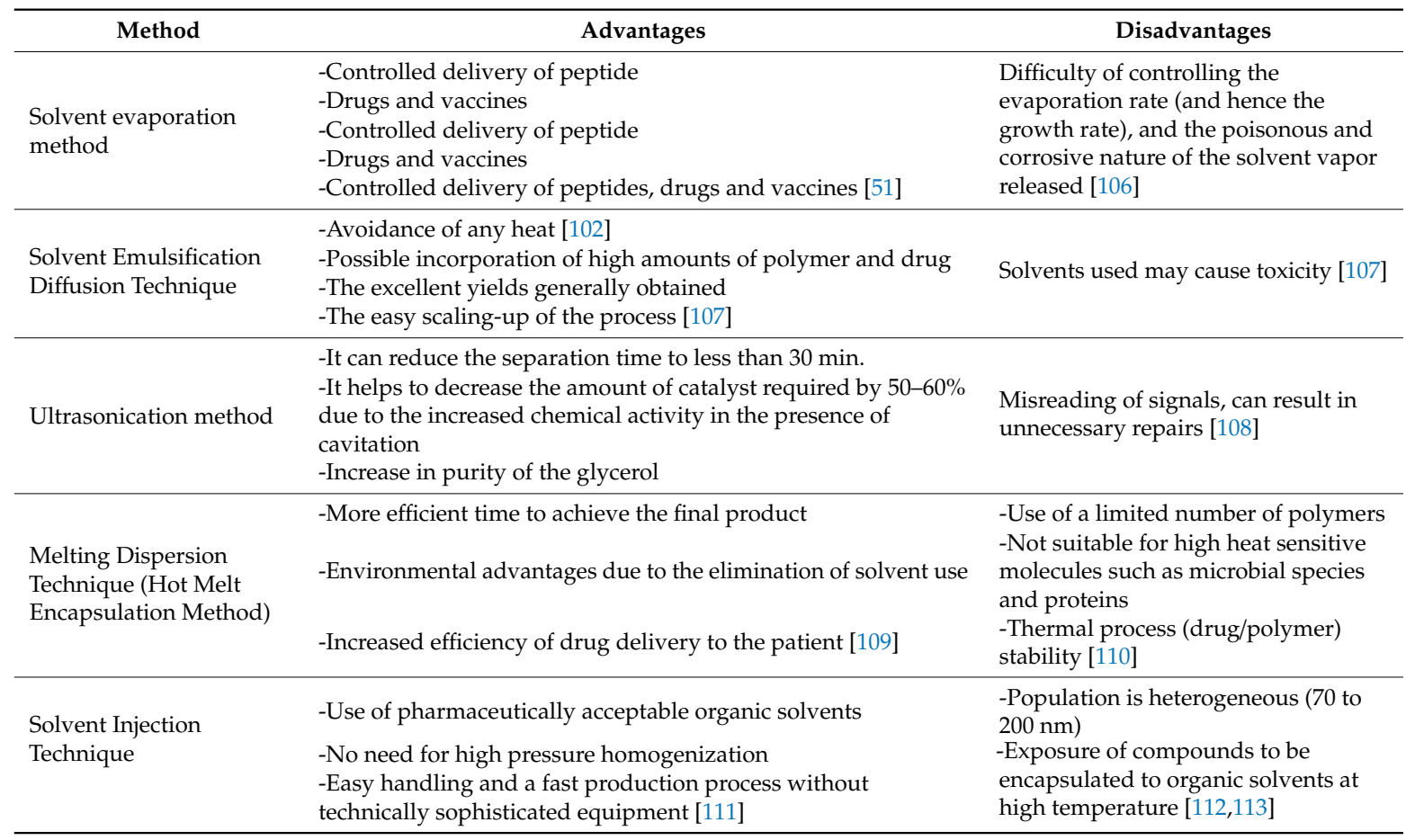

Table 2. Different antioxidants and their fabricated nanosystems in cancer therapy.

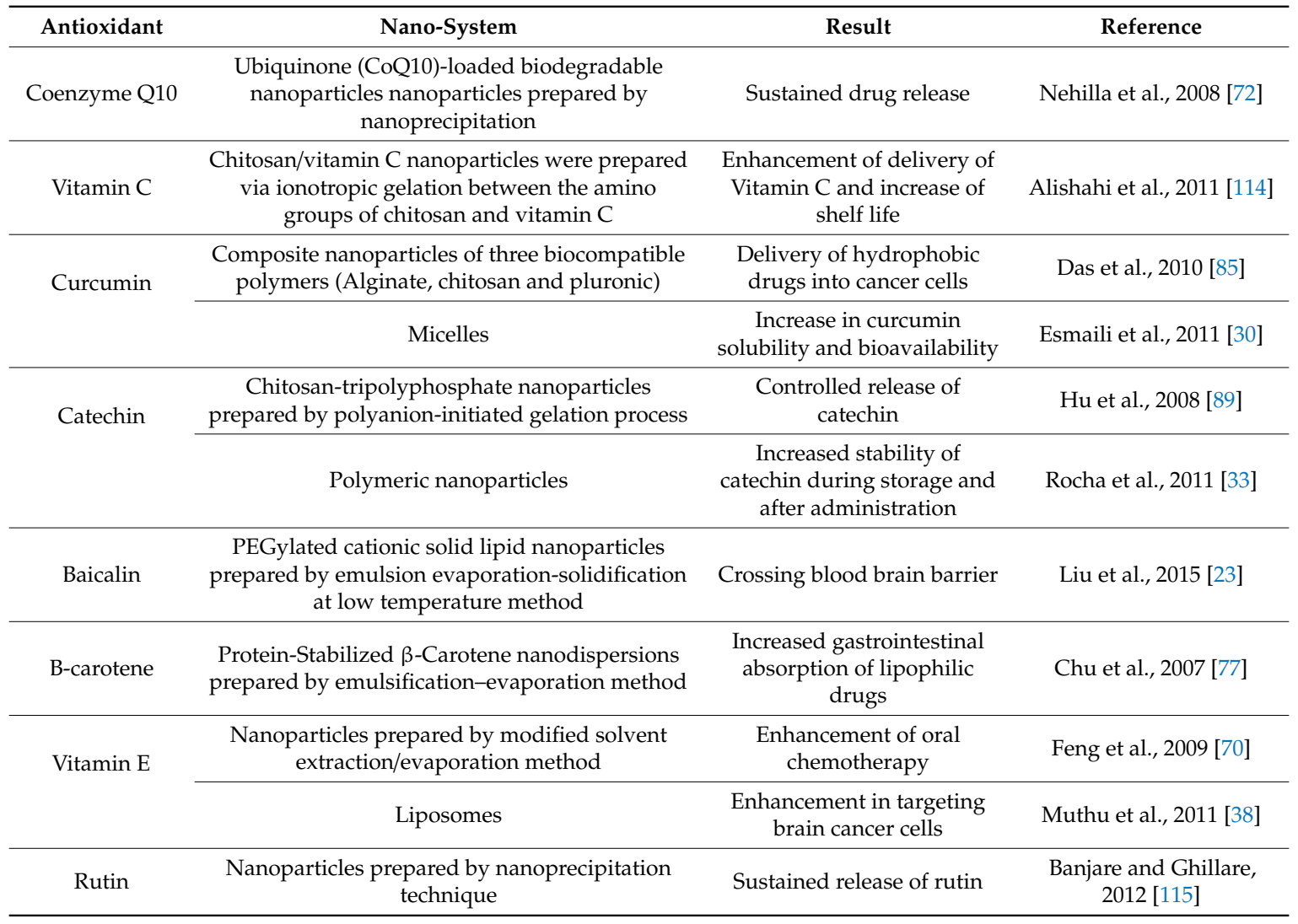

Conflicts of Interest: The authors declare no conflict of interest. 


\section{References}

1. Shewach, D.S.; Kuchta, R.D. Introduction to Cancer Chemotherapeutics; ACS Publications: Washington, DC, USA, 2009.

2. Visconti, R.; Grieco, D. New insights on oxidative stress in cancer. Curr. Opin. Drug Discov. Dev. 2009, 12, 240-245. [PubMed]

3. Reuter, S.; Gupta, S.C.; Chaturvedi, M.M.; Aggarwal, B.B. Oxidative stress, inflammation, and cancer: How are they linked? Free Radic. Biol. Med. 2010, 49, 1603-1616. [CrossRef] [PubMed]

4. Moslen, M. Reactive Oxygen Species in Normal Physiology, Cell Injury and Phagocytosis, Free Radicals in Diagnostic Medicine; Armstrong Plenum Press: New York, NY, USA, 1994.

5. Jagtap, P.; Szabó, C. Poly (ADP-ribose) polymerase and the therapeutic effects of its inhibitors. Nat. Rev. Drug Discov. 2005, 4, 421. [CrossRef] [PubMed]

6. Liaudet, L.; Szabó, É.; Timashpolsky, L.; Virág, L.; Cziráki, A.; Szabó, C. Suppression of poly (ADP-ribose) polymerase activation by 3-aminobenzamide in a rat model of myocardial infarction: Long-term morphological and functional consequences. Br. J. Pharm. 2001, 133, 1424-1430. [CrossRef]

7. Veskoukis, A.S.; Tsatsakis, A.M.; Kouretas, D. Dietary oxidative stress and antioxidant defense with an emphasis on plant extract administration. Cell Stress Chaperones 2012, 17, 11-21. [CrossRef] [PubMed]

8. Müller, R.H.; Mäder, K.; Gohla, S. Solid lipid nanoparticles (SLN) for controlled drug delivery-A review of the state of the art. Eur. J. Pharm. Biopharm. 2000, 50, 161-177. [CrossRef]

9. Hellman, S. Principles of radiation therapy. Cancer Princ. Pract. Oncol. 1993, 1, 269-270.

10. Sangeetha, P.; Das, U.; Koratkar, R.; Suryaprabha, P. Increase in free radical generation and lipid peroxidation following chemotherapy in patients with cancer. Free Radic. Biol. Med. 1990, 8, 15-19. [CrossRef]

11. Weijl, N.; Cleton, F.; Osanto, S. Free radicals and antioxidants in chemotherapyinduced toxicity. Cancer Treat. Rev. 1997, 23, 209-240. [CrossRef]

12. Sharma, M.; Rajappa, M.; Kumar, G.; Sharma, A. Oxidant-antioxidant status in Indian patients with carcinoma of posterior one-third of tongue. Cancer Biomark. 2009, 5, 253-260. [CrossRef]

13. St. Clair, D.K.; Jordan, J.A.; Wan, X.S.; Gairola, C.G. Protective role of manganese superoxide dismutase against cigarette smoke-induced cytotoxicity. J. Toxicol. Environ. Health Part A Curr. Issues 1994, 43, $239-249$. [CrossRef] [PubMed]

14. Wong, G.H. Protective roles of cytokines against radiation: Induction of mitochondrial MnSOD. Biochim. Biophys. Acta (BBA) Mol. Basis Dis. 1995, 1271, 205-209. [CrossRef]

15. Halliwell, B.; Gutteridge, J.M.C.; Cross, C.E. Free radicals, antioxidants, and human disease: Where are we now? Lab. Clin. Med. 1992, 19, 598-620.

16. Singh, K.; Bhori, M.; Kasua, Y.A.; Bhatb, G.; Marar, T. Antioxidants as precision weapons in war against cancer chemotherapyinduced toxicity-Exploring the armoury of obscurity. Saudi Pharm. J. 2018, 26, 177-190. [CrossRef] [PubMed]

17. Shinde, A.; Ganu, J.; Naik, P. Effect of free radicals \& antioxidants on oxidative stress: A review. J. Dent. Allied Sci. 2012, 1, 63-66. [CrossRef]

18. Simone II, C.B.; Simone, N.L.; Simone, V.; Simone, C.B. Antioxidants and other nutrients do not interfere with chemotherapy or radiation therapy and can increase kill and increase survival, Part 2. Altern. Ther. Health Med. 2007, 13, 22-29.

19. Abbasi, E.; Aval, S.F.; Akbarzadeh, A.; Milani, M.; Nasrabadi, H.T.; Joo, S.W.; Hanifehpour, Y.; Nejati-Koshki, K.; Pashaei-Asl, R. Dendrimers: Synthesis, applications, and properties. Nanoscale Res. Lett. 2014, 9, 247. [CrossRef] [PubMed]

20. Caban, S.; Aytekin, E.; Sahin, A.; Capan, Y. Nanosystems for drug delivery. Drug Des. Deliv. $2014,2,2$.

21. Moghimi, S.M.; Hunter, A.C.; Murray, J.C. Nanomedicine: Current status and future prospects. FASEB J. 2005, 19, 311-330. [CrossRef]

22. Zhang, M.; Zhu, J.; Zheng, Y.; Guo, R.; Wang, S.; Mignani, S.; Caminade, A.-M.; Majoral, J.-P.; Shi, X. Doxorubicin-conjugated PAMAM dendrimers for $\mathrm{pH}$-responsive drug release and folic acid-targeted cancer therapy. Pharmaceutics 2018, 10, 162. [CrossRef]

23. Liu, Z.; Zhao, H.; Shu, L.; Zhang, Y.; Okeke, C.; Zhang, L.; Li, J.; Li, N. Preparation and evaluation of Baicalin-loaded cationic solid lipid nanoparticles conjugated with OX26 for improved delivery across the BBB. Drug Dev. Ind. Pharm. 2015, 41, 353-361. [CrossRef] [PubMed] 
24. Kabanov, A.V.; Batrakova, E.V.; Melik-Nubarov, N.S.; Fedoseev, N.A.; Dorodnich, T.Y.; Alakhov, V.Y.; Chekhonin, V.P.; Nazarova, I.R.; Kabanov, V.A. A new class of drug carriers: Micelles of poly (oxyethylene)-poly (oxypropylene) block copolymers as microcontainers for drug targeting from blood in brain. J. Control. Release 1992, 22, 141-157. [CrossRef]

25. Torchilin, V.P. Micellar nanocarriers: Pharmaceutical perspectives. Pharm. Res. 2007, 24, 1. [CrossRef] [PubMed]

26. Loppinet, B.; Monteux, C. Dynamics of surfactants and polymers at liquid interfaces. In Soft Matter at Aqueous Interfaces; Springer: Berlin/Heidelberg, Germany, 2016; pp. 137-157. [CrossRef]

27. Schramm, L.L.; Stasiuk, E.N.; Marangoni, D.G. 2 Surfactants and their applications. Annu. Rep. Sect. C (Phys. Chem.) 2003, 99, 3-48. [CrossRef]

28. Kellermann, M.; Bauer, W.; Hirsch, A.; Schade, B.; Ludwig, K.; Böttcher, C. The first account of a structurally persistent micelle. Angew. Chem. Int. Ed. 2004, 43, 2959-2962. [CrossRef]

29. Moriyama, M.; Metzger, S.; van der Vlies, A.J.; Uyama, H.; Ehrbar, M.; Hasegawa, U. Inhibition of angiogenesis by antioxidant micelles. Adv. Healthc. Mater. 2015, 4, 569-575. [CrossRef]

30. Esmaili, M.; Ghaffari, S.M.; Moosavi-Movahedi, Z.; Atri, M.S.; Sharifizadeh, A.; Farhadi, M.; Yousefi, R.; Chobert, J.-M.; Haertlé, T.; Moosavi-Movahedi, A.A. Beta casein-micelle as a nano vehicle for solubility enhancement of curcumin; food industry application. LWT Food Sci. Technol. 2011, 44, 2166-2172. [CrossRef]

31. Prabhu, R.H.; Patravale, V.B.; Joshi, M.D. Polymeric nanoparticles for targeted treatment in oncology: Current insights. Int. J. Nanomed. 2015, 10, 1001.

32. Mady, F.M.; Shaker, M.A. Enhanced anticancer activity and oral bioavailability of ellagic acid through encapsulation in biodegradable polymeric nanoparticles. Int. J. Nanomed. 2017, 12, 7405. [CrossRef]

33. Rocha, S.; Generalov, R.; Pereira, M.d.C.; Peres, I.; Juzenas, P.; Coelho, M.A. Epigallocatechin gallate-loaded polysaccharide nanoparticles for prostate cancer chemoprevention. Nanomedicine 2011, 6, 79-87. [CrossRef] [PubMed]

34. Safra, T.; Muggia, F.; Jeffers, S.; Tsao-Wei, D.; Groshen, S.; Lyass, O.; Henderson, R.; Berry, G.; Gabizon, A. Pegylated liposomal doxorubicin (doxil): Reduced clinical cardiotoxicity in patients reaching or exceeding cumulative doses of $500 \mathrm{mg} / \mathrm{m}^{2}$. Ann. Oncol. 2000, 11, 1029-1033. [CrossRef] [PubMed]

35. Swenson, C.; Perkins, W.; Roberts, P.; Janoff, A. Liposome technology and the development of Myocet ${ }^{\mathrm{TM}}$ (liposomal doxorubicin citrate). Breast 2001, 10, 1-7. [CrossRef]

36. Boman, N.L.; Bally, M.B.; Cullis, P.R.; Mayer, L.D.; Webb, M.S. Encapsulation of vincristine in liposomes reduces its toxicity and improves its anti-tumor efficacy. J. Liposome Res. 1995, 5, 523-541. [CrossRef]

37. Koudelka, S.; Knotigova, P.T.; Masek, J.; Prochazka, L.; Lukac, R.; Miller, A.D.; Neuzil, J.; Turanek, J. Liposomal delivery systems for anti-cancer analogues of vitamin E. J. Control. Release 2015, 207, 59-69. [CrossRef]

38. Muthu, M.S.; Kulkarni, S.A.; Xiong, J.; Feng, S.-S. Vitamin E TPGS coated liposomes enhanced cellular uptake and cytotoxicity of docetaxel in brain cancer cells. Int. J. Pharm. 2011, 421, 332-340. [CrossRef]

39. Yoon, G.; Park, J.W.; Yoon, I.-S. Solid lipid nanoparticles (SLNs) and nanostructured lipid carriers (NLCs): Recent advances in drug delivery. J. Pharm. Investig. 2013, 43, 353-362. [CrossRef]

40. Müller, R.; Dingler, A.; Schneppe, T.; Gohla, S. Large scale production of solid lipid nanoparticles (SLN $\left.{ }^{\mathrm{TM}}\right)$ and nanosuspensions (DissoCubes ${ }^{\mathrm{TM}}$ ). Handb. Pharm. Control. Release Technol. 2000, 359-376.

41. Gregoriadis, G. Liposomes as Drug Carriers: Recent Trends and Progress; John Wiley \& Sons: Hoboken, NJ, USA, 1988.

42. Mehnert, W.; Mäder, K. Solid lipid nanoparticles: Production, characterization and applications. Adv. Drug Deliv. Rev. 2012, 64, 83-101. [CrossRef]

43. Üner, M. Preparation, characterization and physico-chemical properties of solid lipid nanoparticles (SLN) and nanostructured lipid carriers (NLC): Their benefits as colloidal drug carrier systems. Die Pharm. Int. J. Pharm. Sci. 2006, 61, 375-386.

44. Mukherjee, S.; Ray, S.; Thakur, R. Solid lipid nanoparticles: A modern formulation approach in drug delivery system. Indian J. Pharm. Sci. 2009, 71, 349. [CrossRef]

45. Muller, R.H. Solid lipid nanoparticles (SLN)-an alternative colloidal carrier system for controlled drug delivery. Eur. J. Biopharm. 1995, 41, 62-69.

46. Muller, R.; Dingler, A.; Weyhers, H.; Zur Muhlen, A. Feste lipid nanopartikel (SLN). Pharm. Technol. Mod. Arzneiformen 1997, 265-272. 
47. Hoar, T.P.; Schulman, J.H. Transparent water-in-oil dispersions the oleopathic hydro micelle Nature. Int. J. Pharm. Sci. 1943, 152, 102-103. [CrossRef]

48. Moghimipour, E.; Salimi, A.; Eftekhari, S. Design and characterization of microemulsion systems for naproxen. Adv. Pharm. Bull. 2013, 3, 63. [PubMed]

49. Jin, C.; Bai, L.; Wu, H.; Tian, F.; Guo, G. Radiosensitization of paclitaxel, etanidazole and paclitaxel+ etanidazole nanoparticles on hypoxic human tumor cells in vitro. Biomaterials 2007, 28, 3724-3730. [CrossRef]

50. Tan, C.P.; Nakajima, M. $\beta$-Carotene nanodispersions: Preparation, characterization and stability evaluation. Food Chem. 2005, 92, 661-671. [CrossRef]

51. Hwisa, N.; Katakam, P.; Chandu, B.; Adiki, S. Solvent evaporation techniques as promising advancement in microencapsulation. Vri Biol. Med. Chem. 2013, 1, 8-22. [CrossRef]

52. Jia, L.-J.; Zhang, D.-R.; Li, Z.-Y.; Feng, F.-F.; Wang, Y.-C.; Dai, W.-T.; Duan, C.-X.; Zhang, Q. Preparation and characterization of silybin-loaded nanostructured lipid carriers. Drug Deliv. 2010, 17, 11-18. [CrossRef] [PubMed]

53. Ekambaram, P.; Sathali, A.A.H.; Priyanka, K. Solid lipid nanoparticles: A review. Sci. Rev. Chem. Commun. 2012, 2, 80-102.

54. Reithmeier, H.; Herrmann, J.; Göpferich, A. Lipid microparticles as a parenteral controlled release device for peptides. J. Control. Release 2001, 73, 339-350. [CrossRef]

55. Reithmeier, H.; Herrmann, J.; Göpferich, A. Development and characterization of lipid microparticles as a drug carrier for somatostatin. Int. J. Pharm. 2001, 218, 133-143. [CrossRef]

56. Cortesi, R.; Esposito, E.; Luca, G.; Nastruzzi, C. Production of lipospheres as carriers for bioactive compounds. Biomaterials 2002, 23, 2283-2294. [CrossRef]

57. Jaganathan, K.; Rao, Y.; Singh, P.; Prabakaran, D.; Gupta, S.; Jain, A.; Vyas, S.P. Development of a single dose tetanus toxoid formulation based on polymeric microspheres: A comparative study of poly (D,L-lactic-co-glycolic acid) versus chitosan microspheres. Int. J. Pharm. 2005, 294, 23-32. [CrossRef] [PubMed]

58. Garcia-Fuentes, M.; Torres, D.; Alonso, M. Design of lipid nanoparticles for the oral delivery of hydrophilic macromolecules. Colloids Surf. B Biointerfaces 2003, 27, 159-168. [CrossRef]

59. Reis, C.P.; Neufeld, R.J.; Ribeiro, A.J.; Veiga, F.; Nanoencapsulation, I. Methods for preparation of drug-loaded polymeric nanoparticles. Nanomed. Nanotechnol. Biol. Med. 2006, 2, 8-21. [CrossRef]

60. Rao, J.P.; Geckeler, K.E. Polymer nanoparticles: Preparation techniques and size-control parameters. Prog. Polym. Sci. 2011, 36, 887-913. [CrossRef]

61. Fessi, H.; Puisieux, F.; Devissaguet, J.P.; Ammoury, N.; Benita, S. Nanocapsule formation by interfacial polymer deposition following solvent displacement. Int. J. Pharm. 1989, 55, R1-R4. [CrossRef]

62. Jaiswal, J.; Gupta, S.K.; Kreuter, J. Preparation of biodegradable cyclosporine nanoparticles by high-pressure emulsification-solvent evaporation process. J. Control. Release 2004, 96, 169-178. [CrossRef]

63. Rizvi, S.; Raza, S.T.; Ahmed, F.; Ahmad, A.; Abbas, S.; Mahdi, F. The role of vitamin E in human health and some diseases. Sultan Qaboos Univ. Med. J. 2014, 14, e157. [PubMed]

64. Waxman, S.; Bruckner, H. The enhancement of 5-fluorouracil antimetabolic activity by leucovorin, menadione and $\alpha$-tocopherol. Eur. J. Cancer 1982, 18, 685-692. [CrossRef]

65. Prasad, K.N.; Edwards-Prasad, J.; Ramanujam, S.; Sakamoto, A. Vitamin E increases the growth inhibitory and differentiating effects of tumor therapeutic agents on neuroblastoma and glioma cells in culture. Proc. Soc. Exp. Biol. Med. 1980, 164, 158-163. [CrossRef]

66. Chinery, R.; Brockman, J.A.; Peeler, M.O.; Shyr, Y.; Beauchamp, R.D.; Coffey, R.J. Antioxidants enhance the cytotoxicity of chemotherapeutic agents in colorectal cancer: A p53-independent induction of p21WAF1/CIP1 via C/EBP $\beta$. Nat. Med. 1997, 3, 1233. [CrossRef]

67. Ripoll, E.A.P.; Rama, B.N.; Webber, M.M. Vitamin E enhances the chemotherapeutic effects of adriamycin on human prostatic carcinoma cells in vitro. J. Urol. 1986, 136, 529-531. [CrossRef]

68. Sue, K.; Nakagawara, A.; Okuzono, S.-I.; Fukushige, T.; Ikeda, K. Combined effects of vitamin E (alpha-tocopherol) and cisplatin on the growth of murine neuroblastoma in vivo. Eur. J. Cancer Clin. Oncol. 1988, 24, 1751-1758. [CrossRef]

69. Sonneveld, P. Effect of alpha-tocopherol on the cardiotoxicity of adriamycin in the rat. Cancer Treat. Rep. 1978, 62, 1033-1036. [PubMed] 
70. Feng, S.-S.; Mei, L.; Anitha, P.; Gan, C.W.; Zhou, W. Poly (lactide)-vitamin E derivative/montmorillonite nanoparticle formulations for the oral delivery of Docetaxel. Biomaterials 2009, 30, 3297-3306. [CrossRef] [PubMed]

71. Hurley, L.H.; Allen, C.S.; Feola, J.M.; Lubawy, W.C. In vitro and in vivo stability of anthramycin-DNA conjugate and its potential application as an anthramycin prodrug. Cancer Res. 1979, 39, 3134-3140. [PubMed]

72. Nehilla, B.J.; Bergkvist, M.; Popat, K.C.; Desai, T.A. Purified and surfactant-free coenzyme Q10-loaded biodegradable nanoparticles. Int. J. Pharm. 2008, 348, 107-114. [CrossRef] [PubMed]

73. Spitz, M.R.; McPherson, R.S.; Jiang, H.; Hsu, T.; Trizna, Z.; Lee, J.J.; Lippman, S.M.; Khuri, F.R.; Steffen-Batey, L.; Chamberlain, R.M. Correlates of mutagen sensitivity in patients with upper aerodigestive tract cancer. Cancer Epidemiol. Prev. Biomark. 1997, 6, 687-692. [PubMed]

74. Duarah, S.; Durai, R.D.; Narayanan, V.B. Nanoparticle-in-gel system for delivery of vitamin C for topical application. Drug Deliv. Transl. Res. 2017, 7, 750-760. [CrossRef]

75. Teicher, B.A.; Schwartz, J.L.; Holden, S.A.; Ara, G.; Northey, D. In vivo modulation of several anticancer agents by $\beta$-carotene. Cancer Chemother. Pharmacol. 1994, 34, 235-241. [CrossRef] [PubMed]

76. Prasad, K.N.; Hernandez, C.; Edwards-Prasad, J.; Nelson, J.; Borus, T.; Robinson, W.A. Modification of the effect of tamoxifen, cis-platin, DTIC, and interferon- $\alpha 2 \mathrm{~b}$ on human melanoma cells in culture by a mixture of vitamins. Nutr. Cancer 1994, 22, 233-245. [CrossRef]

77. Chu, B.S.; Ichikawa, S.; Kanafusa, S.; Nakajima, M. Preparation of protein-stabilized $\beta$-carotene nanodispersions by emulsification-evaporation method. J. Am. Oil Chem. Soc. 2007, 84, 1053-1062. [CrossRef]

78. Kampa, M.; Hatzoglou, A.; Notas, G.; Damianaki, A.; Bakogeorgou, E.; Gemetzi, C.; Kouroumalis, E.; Martin, P.-M.; Castanas, E. Wine antioxidant polyphenols inhibit the proliferation of human prostate cancer cell lines. Nutr. Cancer 2000, 37, 223-233. [CrossRef] [PubMed]

79. Manna, S.K.; Mukhopadhyay, A.; Aggarwal, B.B. Resveratrol suppresses TNF-induced activation of nuclear transcription factors NF- $\mathrm{kB}$, activator protein-1, and apoptosis: Potential role of reactive oxygen intermediates and lipid peroxidation. J. Immunol. 2000, 164, 6509-6519. [CrossRef] [PubMed]

80. Thipe, V.C.; Panjtan Amiri, K.; Bloebaum, P.; Raphael Karikachery, A.; Khoobchandani, M.; Katti, K.K.; Jurisson, S.S.; Katti, K.V. Development of resveratrol-conjugated gold nanoparticles: Interrelationship of increased resveratrol corona on anti-tumor efficacy against breast, pancreatic and prostate cancers. Int. J. Nanomed. 2019, 14, 4413-4428. [CrossRef] [PubMed]

81. Penalva, R.; Morales, J.; Gonzalez-Navarro, C.J.; Larraneta, E.; Quincoces, G.; Penuelas, I.; Irache, J.M. Increased Oral Bioavailability of Resveratrol by Its Encapsulation in Casein Nanoparticles. Int. J. Mol. Sci. 2018, 19, 2816. [CrossRef]

82. Menon, V.P.; Sudheer, A.R. Antioxidant and anti-inflammatory properties of curcumin. In The Molecular Targets and Therapeutic Uses of Curcumin in Health and Disease; Springer: Berlin/Heidelberg, Germany, 2007; pp. 105-125.

83. Modasiya, M.; Patel, V. Studies on solubility of curcumin. Int. J. Pharm. Life Sci. 2012, 3, 1490-1497.

84. Modasiya, M.; Patel, V. Curcumin nanoparticles: Preparation, characterization, and antimicrobial study. J. Agric. Food Chem. 2011, 59, 2056-2061. [CrossRef] [PubMed]

85. Das, R.K.; Kasoju, N.; Bora, U. Encapsulation of curcumin in alginate-chitosan-pluronic composite nanoparticles for delivery to cancer cells. Nanomed. Nanotechnol. Biol. Med. 2010, 6, 153-160. [CrossRef]

86. Xu, J.Z.; Yeung, S.Y.V.; Chang, Q.; Huang, Y.; Chen, Z.-Y. Comparison of antioxidant activity and bioavailability of tea epicatechins with their epimers. Br. J. Nutr. 2004, 91, 873-881. [PubMed]

87. Zhu, M.; Chen, Y.; Li, R.C. Oral absorption and bioavailability of tea catechins. Planta Med. 2000, 66, 444-447. [CrossRef] [PubMed]

88. Kaur, S.; Greaves, P.; Cooke, D.N.; Edwards, R.; Steward, W.P.; Gescher, A.J.; Marczylo, T.H. Breast cancer prevention by green tea catechins and black tea theaflavins in the C3 (1) SV40 T, t antigen transgenic mouse model is accompanied by increased apoptosis and a decrease in oxidative DNA adducts. J. Agric. Food Chem. 2007, 55, 3378-3385. [CrossRef] [PubMed]

89. Hu, B.; Pan, C.; Sun, Y.; Hou, Z.; Ye, H.; Zeng, X. Optimization of fabrication parameters to produce chitosan-tripolyphosphate nanoparticles for delivery of tea catechins. J. Agric. Food Chem. 2008, 56, 7451-7458. [CrossRef] 
90. Iriti, M.; Kubina, R.; Cochis, A.; Sorrentino, R.; Varoni, E.M.; Kabała-Dzik, A.; Azzimonti, B.; Dziedzic, A.; Rimondini, L.; Wojtyczka, R.D. Rutin, a quercetin glycoside, restores chemosensitivity in human breast cancer cells. Phytother. Res. 2017, 31, 1529-1538. [CrossRef]

91. Zhang, S.; Han, Y. Preparation, characterisation and antioxidant activities of rutin-loaded zein-sodium caseinate nanoparticles. PLoS ONE 2018, 13, e0194951. [CrossRef]

92. Qi, L.; Zhou, R.; Wang, Y.; Zhu, Y. Study of major flavonoids in crude Scutellariae Radix by micellar electrokinetic capillary chromatography. J. Capill. Electrophor. 1998, 5, 181-184. [PubMed]

93. Cheng, G.; Feng, N.; Tang, Q.; Li, L. Studies on in vitro antibacterial action of baicalin in vitro. Chin. J. Hosp. Pharm. 2001, 21, 347-348.

94. Chung, H.; Choi, H.S.; Seo, E.-K.; Kang, D.-H.; Oh, E.-S. Baicalin and baicalein inhibit transforming growth factor- $\beta 1$-mediated epithelial-mesenchymal transition in human breast epithelial cells. Biochem. Biophys. Res. Commun. 2015, 458, 707-713. [CrossRef]

95. Zhang, H.-B.; Lu, P.; Guo, Q.-Y.; Zhang, Z.-H.; Meng, X.-Y. Baicalein induces apoptosis in esophageal squamous cell carcinoma cells through modulation of the PI3K/Akt pathway. Oncol. Lett. 2013, 5, 722-728. [CrossRef]

96. Chen, J.; Li, Z.; Chen, A.Y.; Ye, X.; Luo, H.; Rankin, G.O.; Chen, Y.C. Inhibitory effect of baicalin and baicalein on ovarian cancer cells. Int. J. Mol. Sci. 2013, 14, 6012-6025. [CrossRef] [PubMed]

97. Wang, X.-F.; Zhou, Q.-M.; Du, J.; Zhang, H.; Lu, Y.-Y.; Su, S.-B. Baicalin suppresses migration, invasion and metastasis of breast cancer via p38MAPK signaling pathway. Anti-Cancer Agents Med. Chem. (Former Curr. Med. Chem. Anti-Cancer Agents) 2013, 13, 923-931.

98. Li, K.; Wang, J.; Shi, M.; Li, J.; Yan, L.; Zhang, H.; Lu, C. Prescription consisting of vitamin C and baicalin inhibits tumor growth by enhancing the antioxidant capacity in vivo. J. Buon. 2015, 20, 1368-1372. [PubMed]

99. Du, G.; Han, G.; Zhang, S.; Lin, H.; Wu, X.; Wang, M.; Ji, L.; Lu, L.; Yu, L.; Liang, W. Baicalin suppresses lung carcinoma and lung metastasis by SOD mimic and HIF-1 $\alpha$ inhibition. Eur. J. Pharmacol. 2010, 630, 121-130. [CrossRef] [PubMed]

100. Yu, Y.; Pei, M.; Li, L. Baicalin induces apoptosis in hepatic cancer cells in vitro and suppresses tumor growth in vivo. Int. J. Clin. Exp. Med. 2015, 8, 8958. [PubMed]

101. Alishahia, A.; Mirvaghefi, A.; Tehrani, M.R.; Farahmand, H.; Shojaosadati, S.A.; Dorkoosh, F.A.; Elsabee, Z.M. Shelf life and delivery enhancement of vitamin C using chitosan nanoparticles. Food Chem. 2011, 126, 935-940. [CrossRef]

102. Banjare, L.; Ghillare, N. Development of biocompatible nanoparticles for sustained topical delivery of Rutin. Int. J. Pharm. Biol. Arch. 2012, 3, 326-332.

103. Patrignani, F.; Lanciotti, R. Applications of high and ultra high pressure homogenization for food safety. Front. Microbiol. 2016, 7, 1132. [CrossRef]

104. Trotta, M.; Debernardi, F.; Caputo, O. Preparation of solid lipid nanoparticles by a solvent emulsification-diffusion technique. Int. J. Pharm. 2003, 257, 153-160. [CrossRef]

105. Ambroziak, K.; Kielczewska, K.; Mickiewicz, D.; Dabrowska, A. Advantages and disadvantages of partial high pressure homogenisation of milk in relation to full-stream homogenisation. Pol. J. Food Nutr. Sci. 2019, 69, 279-287. [CrossRef]

106. Madhav, S.; Gupta, D. A review on microemulsion based system. Int. J. Pharm. Sci. Res. 2011, 2, 1888.

107. Paul, B.K.; Moulik, S.P. Microemulsions: An overview. J. Dispers. Sci. Technol. 1997, 18, 301-367. [CrossRef]

108. Li, M.; Rouaud, O.; Poncelet, D. Microencapsulation by solvent evaporation: State of the art for process engineering approaches. Int. J. Pharm. 2008, 363, 26-39. [CrossRef]

109. Quintanar-Guerrero, D.; Allémann, E.; Fessi, H.; Doelker, E. Preparation techniques and mechanisms of formation of biodegradable nanoparticles from preformed polymers. Drug Dev. Ind. Pharm. 1998, 24, 1113-1128. [CrossRef]

110. Gholizadeh, S. A review of non-destructive testing methods of composite materials. Procedia Struct. Integr. 2016, 1, 50-57. [CrossRef]

111. Patil, H.; Tiwari, R.V.; Repka, M.A. Hot-melt extrusion: From theory to application in pharmaceutical formulation. Aaps Pharmscitech 2016, 17, 20-42. [CrossRef]

112. Maniruzzaman, M.; Boateng, J.S.; Snowden, M.J.; Douroumis, D. A review of hot-melt extrusion: Process technology to pharmaceutical products. ISRN Pharm. 2012, 2012, 436763. [CrossRef] 
113. Schubert, M.; Müller-Goymann, C. Solvent injection as a new approach for manufacturing lipid nanoparticles-evaluation of the method and process parameters. Eur. J. Pharm. Biopharm. 2003, 55, 125-131. [CrossRef]

114. Deamer, D.; Bangham, A. Large volume liposomes by an ether vaporization method. Biochim. Biophys. Acta (BBA) Nucleic Acids Protein Synth. 1976, 443, 629-634. [CrossRef]

115. Schieren, H.; Rudolph, S.; Finkelstein, M.; Coleman, P.; Weissmann, G. Comparison of large unilamellar vesicles prepared by a petroleum ether vaporization method with multilamellar vesicles: ESR, diffusion and entrapment analyses. Biochim. Biophys. Acta (BBA) Gen. Subj. 1978, 542, 137-153. [CrossRef]

(C) 2020 by the authors. Licensee MDPI, Basel, Switzerland. This article is an open access article distributed under the terms and conditions of the Creative Commons Attribution (CC BY) license (http://creativecommons.org/licenses/by/4.0/). 